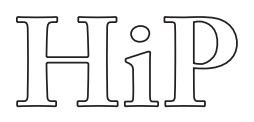

Historia i Polityka

$\mathrm{Nr} 13(20) / 2015$, ss. $129-140$

ISSN 1899-5160

www.hip.umk.pl

DOI: http://dx.doi.org/10.12775/HiP.2015.008

Maciej WOJTACKI

Wyższa Szkoła Kultury Społecznej i Medialnej, Toruń

\title{
Krajowe Stronnictwo Ludowe Ziem Litewsko-Białoruskich „Zjednoczenie” i jego organ prasowy „Wioska” w kampanii wyborczej do Sejmu II kadencji (1928-1930)
}

\author{
Native Peasants' Party of Lithuanian-Belorussian Lands "Unification" \\ and Its Press Organ "Village" in the Election Campaign \\ for the Second Term Sejm (1928-1930)
}

\begin{abstract}
In this article the political and publishing activity of the Native Peasants' Party of Lithuanian-Belorussian Lands 'Unification' was presented, which has hitherto been omitted in the studies of the history of Polish political parties in the interwar period. The formation of this new political organization was inspired by the central authorities of Pilsudski's ruling camp. Its main task was to keep under surveillance, and finally take over or split political structures of peasants' and Belorussian parties acting in the northeastern provinces of the Second Republic of Poland (those of Vilnius and Nowogrodek), which in the assessment of the representatives of the post-May regime could pose a threat to the electoral register of the Nonpartisan Bloc for Cooperation with the Government. Similar activities were undertaken by supporters of Pilsudski during the election campaign for the Second Term Sejm (1928-1930) all over the country. The press organ of the new party was a weekly 'Village', which was published at the beginning of 1928. Apart from that, the party's authorities issued their announcements and political programme on the pages of 'Kurier Wilenski' and 'Białoruski Dzień'. The latter title functioned as a platform for Native Peasants' Party of Lithuanian-Belorussian Lands 'Unification' aimed at the Belorussian population inhabiting the so-called Eastern borderlands of the Second Republic of Poland.
\end{abstract}

Keywords: peasant movement, Vilnius region, history of the press, election campaign, interwar period

Słowa kluczowe: ruch ludowy, Wileńszczyzna, historia prasy, kampanie wyborcze, międzywojnie

Wobec zbliżającego się końca prac Sejmu I kadencji (1922-1927) większość partii i stronnictw politycznych rozpoczęła przygotowania do kampanii wyborczej. Szczególną rolę w jej trakcie miała odegrać prasa, będąca wówczas jedynym powszechnym, ogólnopolskim medium. To na jej łamach rozegrać się miała głów- 
na batalia o rząd dusz wyborców. Również obóz pomajowy skupiony wokół osoby Marszałka Józefa Piłsudskiego, od jesieni 1927 roku prowadził działania mające na celu wzmocnienie swej pozycji na rynku prasowym. Odnosiły się one głównie do prasy codziennej, która szczególnie w większych ośrodkach miejskich pełniła poza funkcją informacyjną funkcje opiniotwórcze i propagandowe. Jak wskazywał Andrzej Notkowski, to właśnie w okresie kampanii wyborczej do Sejmu II kadencji (1928-1930) liczba nowo powstałych pism codziennych i tygodników, była rekordowa względem tak roku 1922 jak i 1930¹. Również skala środków, które przeznaczono wówczas na akcję propagandową z pewnością przekraczała 8 milionów złotych z funduszu dyspozycyjnego Prezesa Rady Ministrów, których użycie na cele kampanii wyborczej przez ówczesnego ministra skarbu, zostało ujawnione w trakcie tzw. afery Czechowicza². Część z tej kwoty została skierowana na akcję propagandową w województwach wschodnich, w tym będących przedmiotem niniejszych rozważań nowogródzkiego i wileńskiego. Ich skali ze względu na zniszczenie dokumentacji Sekretariatu Generalnego BBWR oraz fakt, że większość dyspozycji finansowych była pokłosiem tajnych narad i była wydawana ustnie bądź telefonicznie $^{3}$, nie można jednak szczegółowo udokumentować i określić.

\section{Powstanie i działalność Krajowego Stronnictwa Ludowego Ziem Litewsko-Białoruskich „Zjednoczenie” (1927-1928)}

Na ziemiach północno-wschodnich II Rzeczpospolitej głównymi siłami opozycyjnymi wobec obozu piłsudczykowskiego były narodowa-demokracja (wówczas jeszcze występująca pod szyldem Związku Ludowo-Narodowego), obóz ludowy, w omawianym okresie przede wszystkim Stronnictwo Chłopskie i PSL „Wyzwolenie”, oraz mniejszość białoruska, tworząca na tym terenie liczne organizacje i partie polityczne. Każdy z wymienionych ośrodków politycznych posiadał na ziemiach północno-wschodnich rozwinięte struktury opierające swe działanie o pełniącą funkcje propagandowe prasę. W przypadku Związku Ludowo-Narodowego najważniejszym organem prasowym w tym rejonie Rzeczypospolitej był „Dziennik Wileński” oraz tygodnik „Głos Wileński”.

1 A. Notkowski, Zza kulis „akcji prasowej” rządów pomajowych w Polsce (1926-1939). O ukrytym finansowaniu wydawnictw, [w:] „Literatura, Prasa, Biblioteka”. Studia i szkice ofiarowane profesorowi Jerzemu Jarowieckiemu w 65-lecie urodzin i 40-lecie pracy, red. J. Szocki, K. Woźniakowski, Kraków 1997, s. 125.

2 A. Ajnenkiel, Parlamentaryzm II Rzeczypospolitej, Warszawa 1978, s. 283-289.

${ }^{3}$ Ibidem, s. 123-126. 
Odmiennie wyglądała sytuacja ruchu ludowego, który pomimo podejmowanych od początku okresu międzywojennego prób stworzenia własnego organu prasowego na terenie wymienionych województw, od połowy lat 20. swą aktywność w zakresie akcji prasowej ograniczył do dystrybucji na ziemiach północno-wschodnich swych ogólnopolskich organów4 ${ }^{4}$ Na przełomie roku 1927 i 1928, w województwie wileńskim wzrastały wpływy Stronnictwa Chłopskiego, którego pismo „Gazeta Chłopska” rozchodziło się wśród miejscowej ludności w nakładzie około dziewięciu tysięcy egzemplarzy. Natomiast konkurencyjne "Wyzwolenie" znajdowało na kresach jedynie trzy tysiące czytelników5.

Ludność białoruska na Wileńszczyźnie i Nowogródczyźnie nie posiadała jednolitej organizacji politycznej, dzieląc się na liczne frakcje i stronnictwa polityczne, wśród których przewagę w drugiej połowie lat 20. XX zaczęła zyskiwać komunizująca „Hromada”. Po aresztowaniach jej liderów wiosną 1927 roku, radykalizacja ruchu białoruskiego na ziemiach północno-wschodnich II Rzeczpospolitej nieco osłabła, co w okresie kampanii wyborczej pozwoliło na aktywizację środowisk wypowiadających się za współpracą z rządem polskim ${ }^{6}$. Władze administracyjne w przeddzień kampanii wyborczej do Sejmu II kadencji wymieniały pięć głównych białoruskich grup politycznych na ziemiach północno-wschodnich II Rzeczpospolitej: 1. Białoruski Centralny Komitet Wyborczy Bloku Mniejszości Narodowych, w skład którego wchodziły Białoruski Związek Włościański, Chrześcijańska Demokracja oraz Białoruskie Zjednoczenie Prawosławne; 2. Prawica Hromady wraz z Białoruską Partią Włościańską; 3. Lewica Hromady współpracująca na terenie województw północno-wschodnich z PPS „Lewicą”; 4. Radykalna Partia Białoruska Franciszka Umiastowskiego wraz z Krajowym Stronnictwem Ludowym; 5. Białoruska Partia Narodowa Arsenia Pawlukiewicza ${ }^{7}$. Konsekwencją wyraźnego rozbicia politycznego mniejszości białoruskiej, był brak jednolitego organu prasowego reprezentującego jej interesy na ziemiach wschodnich II Rzeczpospolitej. Pod koniec lat 20. XX wieku na Wileńszczyźnie wydawanych było kilka pism, reprezentujących liczne białoruskie stronnictwa i grupy politycz-

${ }^{4}$ Pierwszym pismem ludowym była założona przez Polski Związek Ludowy na Litwie w roku 1919 Gazeta Ludowa. W latach 1921-1922 PSL „Piast” wydawało na Wileńszczyźnie Słowo Wileńskie. Mniej więcej w tym samym czasie PSL „Wyzwolenie” wydawało z przerwami tygodniki Wyzwolenie Ludu i Wyzwolenie-Odrodzenie. Zob: A. Paczkowski, Prasa polityczna ruchu ludowego (1918-1939), Warszawa 1970, s. 145-147.

5 Archiwum Akt Nowych (AAN), Ministerstwo Spraw Wewnętrznych (MSW) - dopływ 849, Polityczny Komunikat Informacyjny nr 4/1928, k. 51.

${ }^{6}$ J. Traczuk, Prasa białoruska w II Rzeczypospolitej (1918-1939), Studia Polono-Slavica Orientalia. Acta Litteraria 1992, T. 13, s. 224-232.

7 Lietuvos Centrinis Valstybes Archyvas (dalej LCVA), F. 15-2-378, k. 16-16v. 
ne, między innymi radykalne periodyki: „Naród”, „Nasza Praca” i „Praca” oraz stojące na przeciwległym biegunie czasopisma organizacji lojalnych względem rządu polskiego to jest „Białoruski Dzień” Umiastowskiego i „Białoruskaja Dumka” Pawlukiewicza ${ }^{8}$.

W celu pozyskania wyborców związanych z ruchem ludowym oraz lojalnie ustosunkowanych do państwa polskiego przedstawiciele mniejszości białoruskiej i litewskiej, w listopadzie 1927 powołali do życia Krajowe Stronnictwo Ludowe Ziem Litewsko-Białoruskich - „Zjednoczenie” (dalej KSL „Zjednoczenie” lub Krajowe Stronnictwo Ludowe). Na jego czele stali oddelegowani w tym celu przez przedstawicieli obozu pomajowego, działacze ludowi sympatyzujący z sanacją, m.in. adwokat Mieczysław Raczkiewicz, wcześniej członek PSL „Wyzwolenie” i inżynier Józef Mikułowski. Do końca roku dołączyli do nich byli posłowie: Jan Adamowicz (PSL „Wyzwolenie”), Adolf Dubrownik (PSL „Piast”), Stanisław Hellman (PSL „Wyzwolenie”), Bronisław Wędziagolski (PSL „Piast”), nieznany z imienia Węckowicz, a także wileńscy krajowcy w osobach Witolda Abramowicza i Ludwika Chomińskiego. Konserwatywne „Słowo” wymieniało wśród sympatyków stronnictwa również brata Marszałka Józefa Piłsudskiego - Jana?.

Pierwsze informacje o nowym stronnictwie pojawiają się w połowie listopada 1927 roku a ich źródłem są przygotowywane przez Wydział Bezpieczeństwa Wileńskiego Urzędu Wojewódzkiego meldunki sytuacyjne oraz polska prasa wychodząca w Wilnie.

W połowie listopada odezwę informującą o utworzeniu na ziemiach litewsko-białoruskich KSL „Zjednoczenie”, wydają lokalne struktury PSL „Wyzwolenie” i Stronnictwa Chłopskiego ${ }^{10}$. Natomiast datą, którą z dużym prawdopodobieństwem można uznać za moment ukonstytuowania się Krajowego Stronnictwa Ludowego jest 27 listopada 1927, kiedy to w Wilnie odbył się zjazd okręgowy partii ludowych, szumnie okrzyknięty przez prasę sanacyjną Kongresem Ludowym. Brali w nim udział członkowie dwóch wymienionych partii ludowych oraz Związku Drobnych Rolników Ziem Wschodnich i Radykalnej Partii Białoruskiej Franciszka Umiastowskiego, którzy podjęli uchwałę o powołaniu nowego stronnictwa ${ }^{11}$.

Powstanie nowego stronnictwa wywołało pewien oddźwięk w lokalnych sferach sanacyjnych. Stosunek do KSL „Zjednoczenie” odzwierciedlał również linie podziału w ramach wileńskich struktur BBWR, w których dochodziło do wyraź-

\footnotetext{
${ }^{8}$ J. Traczuk, op. cit., s. 224-232.

9 LCVA, F. 15-2-379, k. 32; Przedwyborczy cymbat brzmiacy, Słowo, 19.11.1927, s. 1.

10 (lit.), Pierwszy krok, Kurier Wileński, 18.02.1927, s. 1.

${ }^{11}$ „Zjednoczenie”, Wioska 1928, nr 2, s. 1-3.
} 
nej różnicy zdań pomiędzy konserwatystami skupionymi wokół „Słowa” a „naprawiaczami”, których organami były „Kurier Wileński” i „Państwo”. Wyraźnie pozytywnie jego działalność oceniano na łamach „Kuriera Wileńskiego”, który do momentu powstania „Wioski” użyczał swych łamów przedstawicielom „Zjednoczenia" ${ }^{12}$. Odmienną opinię na temat nowego bytu politycznego przedstawiono na łamach „Słowa”. Jej podstawą była całkowita negacja przez wileńskich konserwatystów programu autonomii, formułowanego przez nowy odłam „krajowców” ${ }^{13}$.

Powstanie nowego stronnictwa politycznego miało być wyrazem zjednoczenia szerokich warstw społeczeństwa wiejskiego ziem północno-wschodnich niezależnie od dotychczasowych sympatii politycznych i przynależności narodowej. Jedynym kryterium identyfikacyjnym miało być miejsce zamieszkania na ziemiach litewsko-białoruskich i będąca jego pochodną tożsamość zbiorowa części ich mieszkańców określana mianem „krajowości”. Pojęcie to, mające charakter konstytutywny dla nowej organizacji politycznej, było już przedmiotem licznych rozważań i analiz historyków, politologów i prawników ${ }^{14}$. Na użytek niniejszego artykułu przyjmuję definicję krajowości jako specyficznej tożsamości mieszkańców ziem byłego Wielkiego Księstwa Litewskiego, wynikającej z poczucia odrębności tak terytorialnej, jak i kulturowej względem pozostałych ziem Rzeczypospolitej. Odrębność ta ukształtowana po części w kontrze wobec narastającego na przełomie XIX i XX wieku nacjonalizmu litewskiego, a po 1918 roku również wobec nacjonalizmu polskiego, opierała się na dwuszczeblowej tożsamości narodowej wyrażającej się najpełniej w stwierdzeniu Genthe Lithuanus, natione Polonus.

Szczegółowo program nowej partii charakteryzowano na łamach jego organu prasowego "Wioska” - którego działalność wydawnicza, zostanie przedstawiona w dalszej części artykułu. Do głównych celów nowego stronnictwa należeć miały działania, określone w ramach trzech głównych haseł wyborczych, prezentowanych w wyżej wymienionym czasopiśmie, w których stwierdzano:

_ „Żądamy autonomii terytorialnej”;

- „Żądamy zabezpieczenia włościanom taniego opału i drzewa na budowę”;

12 (lit.), Pierwszy krok...; idem, „Bez owijania w bawetnę”, Kurier Wileński, 23.11.1927, s. 1; idem, Pod hastem krajowym, Kurier Wileński, 27.11.1927, s. 1; idem, Zwycięstwo idei krajowej, Kurier Wileński, 29.11.1927, s. 1.

13 Przedwyborczy cymbat brzmiacy...

${ }_{14}$ Wspomnieć należy najważniejsze prace, omawiające bądź poruszające to zagadnienie: J. Bardach, O świadomości narodowej na Litwie i Biatorusi, [w:] Między Polska etniczna a historyczna, red. W. Wrzesiński, Wrocław 1988; Krajowość - tradycje zgody narodów w dobie nacjonalizmu, red. J. Jurkiewicz, Poznań 1999; J. Jurkiewicz, Rozwój polskiej myśli politycznej na Litwie i Białorusi w latach 1905-1922, Poznań 1983; D. Szpoper, Sukcesorzy Wielkiego Księstwa. Myśl polityczna i działalność konserwatystów polskich na ziemiach litewsko-białoruskich w latach 1904-1939, Gdańsk1999. 
- „Żądamy bezpłatnego przeprowadzenia komasacji”.

Program autonomii wynikał bezpośrednio z założeń ideologii krajowej. W praktycznym ujęciu, wyrażał się on jednak w dążeniu do wyboru przedstawicieli związanych z regionem byłego Wielkiego Księstwa Litewskiego oraz decentralizacji procesów decyzyjnych dotyczących województw północno-wschodnich II Rzeczpospolitej. Program stronnictwa zakładał w tym zakresie dążenie do utworzenia lokalnego organu na kształt Sejmu wileńskiego z roku 1922 o kompetencjach podobnych do Sejmu Śląskiego, do którego uprawnień należeć miało kształtowanie polityki oświatowej, opieki społecznej, kwestii agrarnych w tym realizacji reformy rolnej oraz zarząd lokalną administracją, samorządem oraz poli$\mathrm{cją}^{15}$. Nie był to postulat nowy, albowiem co jakiś czas był on poruszany w lokalnej prasie, między innymi w „Kurierze Wileńskim” i „Słowie”, które również odwoływały się w swej retoryce do elementów „krajowości”.

Pozostałe dwa hasła były ściśle związane z potrzebami ludności wiejskiej, a szczególnie z realizacją reformy rolnej. Gwarancją jej wprowadzenia miało być stworzenie jednolitego stronnictwa ludowego, które miało reprezentować interesy włościan kresowych w ramach jej realizacji.

Program stronnictwa nie miał jednak zostać zrealizowany. Jak wynika $\mathrm{z}$ analizy materiałów źródłowych, głównym celem KSL „Zjednoczenie” było realizowanie zadań politycznych, określonych prawdopodobnie przez zarządzającego bezpośrednio akcją wyborczą względem opozycyjnych stronnictw ludowych Kazimierza Świtalskiego ${ }^{16}$. Powstanie nowej organizacji nie byłoby bowiem możliwe bez rozłamu jakiego w Stronnictwie Chłopskim na kresach wschodnich II Rzeczpospolitej dokonał wspomniany Raczkiewicz. Po powstaniu Krajowego Stronnictwa Ludowego, podobne działania Raczkiewicz podjął względem struktur PSL „Wyzwolenia” na terenie województwa wileńskiego. Zakończyły się one połowicznym sukcesem. W trakcie zjazdu „Wyzwolenia”, który odbył się w pierwszej połowie grudnia 1927, działacze skierowani na jego obrady przez Raczkiewicza próbowali przeprowadzić rezolucję zjednoczeniową z KSL „Zjednoczenie”. W przeciwnym wypadku mieli doprowadzić do rozbicia zjazdu. Poza tym przedstawiciele stronnictwa „krajowego" mieli dążyć do objęcia funkcji instruktorów terenowych „Wyzwolenia”, a następnie przejmować jego regionalne struktury i członków. Ostatecznie Raczkiewiczowi nie udało się osiągnąć zakładanych celów, zjazd kierowany przez pochodzącą z Wilna senator PSL „Wyzwolenia” Aleksandrę Karnicką odbył się bez

${ }^{15}$ Pod wtasnym sztandarem, Wioska 1928, nr 1, s. 1-2.

${ }^{16}$ Szerzej o akcji wyborczej prowadzonej przez grupy prorządowe wśród stronnictw ludowych w trakcie kampanii do Sejmu II kadencji, pisał między innymi: A. Paczkowski, op. cit., s. 239-242. 
przeszkód, nie przyjmując uchwały o połączeniu z Krajowym Stronnictwem Ludowym. Jednakże jak podkreślano w meldunku sytuacyjnym, zjazd ukazał wyraźny spadek znaczenia stronnictwa na Wileńszczyźnie, a w jego trakcie przeważały nastroje neutralne względem nowego stronnictwa krajowego, co pozwala sądzić, że część jego członków widziała możliwość współpracy z piłsudczykami ${ }^{17}$.

Przełom roku, to czas największego wzrostu liczby członków nowego stronnictwa, którego efektem był jego kolejny zjazd 15 stycznia 1928 roku. W tym czasie aktywne działania stronnictwa koncentrowały się niemal wyłącznie na rozbudowaniu struktur partii w terenie. W tym celu korzystano głównie z instruktorów pochodzących z organizacji tworzących stronnictwo, sukcesywnie przejmując ich działaczy i zaplecze. Już w połowie grudnia 1927 roku KSL „Zjednoczenie” miało przejąć sekretariat i akta organizacyjne Związku Drobnych Rolników. Poza tym w akcji wyborczej stronnictwa aktywnie uczestniczyli studenci Uniwersytetu Stefana Batorego zrzeszeni w Akademickim Związku Młodzieży Ludowej ${ }^{18}$.

Pomimo tej szerokiej akcji propagandowej i organizacyjnej podejmowanej przez Raczkiewicza, za fundusze uzyskane prawdopodobnie ze strony obozu rządowego, stronnictwo nie osiągnęło poważniejszych wpływów w miejscowym społeczeństwie $^{19}$. W świetle analizowanych materiałów można jednak zaryzykować stwierdzenie, że nie było to celem nowego odłamu „krajowców”, którego głównym zadaniem było podejmowanie działań na rzecz infiltracji, a w konsekwencji osłabienia wpływów organizacji dotychczas negatywnie nastawionych do rządów sanacyjnych $^{20}$. Szczególnie duże straty wizerunkowe miała ponieść Białoruska Partia Radykalna, która w wyniku sojuszu z Krajowym Stronnictwem Ludowym miała zanotować wyraźny spadek poparcia ze strony ludności białoruskiej, która jak podkreślano, z reguły negatywnie ustosunkowywała się do polskich ugrupowań politycznych ${ }^{21}$. Pomimo to w pierwszej połowie stycznia do lokalu KSL „Zjednoczenie” przy ulicy Mostowej 9, przeniesiono redakcję związanego z Białoruską Partią Radykalną redagowanego przez Umiastowskiego tygodnika „Białoruski Dzień”22. O zasięgu terytorialnym stronnictwa świadczy liczba jego oddziałów regionalnych. Na początku stycznia 1928 roku partia informowała o działalności swych sekretariatów powiatowych w Lidzie, Oszmianie, Głębokim, Wilejce, Święcianach, Postawach, Mołodecznie, Baranowiczach, Lubczy i Słonimie. Pla-

${ }_{17}$ LCVA, F 15-2-378, k. 20v., 23, 25; LCVA, F 15-2-379, k. 44, 47-48.

${ }^{18}$ LCVA, F 15-2-379, k. 36.

19 LCVA, F 15-2-378, k. 12v., 13.

${ }^{20}$ LCVA, F 15-2-379, k. 40, 44.

${ }^{21}$ LCVA, F 15-2-378, k. 12.

${ }^{22}$ LCVA, F 15-2-379, k. 10. 
nowano również otwarcie kolejnych między innymi w Brasławiu, Grodnie, Stołpcach i Widzach ${ }^{23}$. W styczniu 1928 roku utworzono również partię „Odrodzenie” Stefana Mickiewicza, której oferta programowa skierowana była do ludności białoruskiej i litewskiej i która podobnie jak KSL dążyła do osłabienia wpływów stronnictw KSL „Zjednoczenie” ugrupowań negatywnie odnoszących się tak do państwowości polskiej jak i obozu rządowego ${ }^{24}$.

Pomimo wzrostu liczby członków i sukcesów organizacyjnych, na początku roku 1928 przedstawiciele Krajowego Stronnictwa Ludowego weszli w skład Bezpartyjnego Bloku Współpracy z Rządem (dalej BBWR) podporządkowując struktury partii zorganizowanemu w Wilnie Wojewódzkiemu Biuru Wyborczemu BBWR, na czele którego stał Wacław Wyszyński ${ }^{25}$. Jak wynika z meldunków sytuacyjnych, decyzję o przyłączeniu się KSL „Zjednoczenie” do Bloku podjęto w Warszawie, w trakcie konsultacji, które odbył tam na początku stycznia 1928 roku Raczkiewicz, a potwierdził ją już post factum Zarząd Główny stronnictwa na posiedzeniu w dniu 21 stycznia ${ }^{26}$. Można więc przypuszczać, że decyzja Raczkiewicza ściśle konsultowana z warszawskimi decydentami, była jednym z elementów zarysowanej już powyżej ogólnopolskiej akcji obozu rządowego, która zmierzała do osłabienia poparcia dla stronnictw opozycyjnych.

W tym samym źródle wskazywano również na finansowe podłoże sojuszu z sanacją. Stronnictwo miało bowiem mieć poważne problemy finansowe, które skłaniały część działaczy do wycofania się z kampanii wyborczej. W tym czasie pomoc mieli zaoferować przedstawiciele Bloku. Jej ceną miała być akcesja Krajowego Stronnictwa Ludowego do koalicji tworzonej przez środowiska sanacyjne na ziemiach północno-wschodnich ${ }^{27}$. O finansowych kłopotach stronnictwa mogą, również świadczyć podejmowane przez część jego członków rozmowy ze Stronnictwem Chłopskim, których celem było powołanie wspólnej listy wyborczej na ziemiach północno-wschodnich II Rzeczpospolitej ${ }^{28}$.

Akces do BBWR spotkał się z krytyką części środowisk ludowych tworzących stronnictwo i doprowadził do wystąpienia z niego struktur SCh oraz wspomnianych już byłych posłów Adamowicza, Dubrownika i Wędziagolskiego ${ }^{29}$. Wynikać

\footnotetext{
23 Sekretariaty powiatowe Krajowego Stronnictwa Ludowego „Zjednoczenie”, Wioska 1928, nr 1, s. 8 .

24 LCVA, F 15-2-378, k. 12v., 13.

25 Ibidem, k. 11-11v.

26 LCVA, F 15-2-379, k. 4.

27 Ibidem, k. 140

28 Ibidem, k. 139.

29 Ibidem, k. 119, 121, 123.
} 
to mogło z faktu iż wobec zaogniania się kampanii wyborczej sekretariat stronnictwa zdecydował o przekazaniu do dyspozycji Bloku nie tylko swych środków materialnych - czego konsekwencją było sukcesywne ograniczanie przejmowanych i rozbudowywanych wcześniej struktur KSL „Zjednoczenie” i Białoruskiej Partii Radykalnej - ale także wszystkich instruktorów i płatnych agitatorów. Kolejną przyczyną konfliktów w ramach stronnictwa, wynikającą bezpośrednio z sojuszu z BBWR, był sprzeciw „tutejszych” włościan, wynikający z faktu, iż w skład Bloku wchodziły organizacje reprezentujące osadników wojskowych, traktowane przez miejscową ludności wiejską jako narzędzie polonizacji tzw. kresów wschodnich ${ }^{30}$. Ich działalność stała więc w jawnej sprzeczności z deklarowaną w programie Krajowego Stronnictwa Ludowego autonomią dla ziem litewsko-białoruskich. Narastające w ramach stronnictwa konflikty doprowadziły również do usunięcia z grona jego członków prezesa Związku Drobnych Rolników, wspomnianego już byłego posła „Wyzwolenia” - Helmana, który wcześniej deklarował odejście z KSL "Zjednoczenie” do Partii Pracy, wraz z grupą swych zwolenników. Przyczyną konfliktu w tym wypadku, była próba umieszczenia przez władze stronnictwa na czele listy w okręgu nowogródzkim byłego posła "Wyzwolenia” Antoniego Hatki, który w ocenie Helmana było osobą "całkowicie skompromitowaną pod kątem moralnym”. Po przyłączeniu się KSL „Zjednoczenie” do BBWR zaobserwowano również, że część działaczy wywodzących się ze środowisk lewicowych, bądź to zaniedbywała swoje obowiązki agitacyjne, bądź jawnie występowała przeciwko programowi Bloku i jego działalności na ziemiach wschodnich II RP ${ }^{31}$.

Po akcesie Krajowego Stronnictwa Ludowego do struktur BBWR, działalność stronnictwa uległa ograniczeniu, a następnie wygaszeniu wraz z zakończeniem kampanii wyborczej. Startujący z sanacyjnej listy przedstawiciele stronnictwa uzyskali bowiem mandaty z ramienia Bezpartyjnego Bloku. Również „Kurier Wileński”, który przed wyborami na bieżąco informował o działalność KSL "Zjednoczenie” i jego kandydatów, omawiając wyniki wyborów i podział mandatów do Sejmu II kadencji z okręgów północno-wschodnich nie uwzględniał stronnictwa jako autonomicznego względem BBWR bytu politycznego ${ }^{32}$.

30 Ibidem, k. 27, 140.

31 Ibidem, k. 80, 123.

32 (lit.), Lista prorządowa na Ziemiach Litewsko-Biatoruskich, Kurier Wileński, 4.02.1928, s. 1; idem, Po walnym zwycięstwie, Kurier Wileński, 6.03.1928, s. 2. 


\section{„Wioska” - organ prasowy Krajowego Stronnictwa Ludowego Ziem Litewsko-Białoruskich „Zjednoczenie”}

W pierwszym okresie działalności stronnictwa to jest do końca roku 1927 funkcję nieformalnego organu stronnictwa, jak już wskazano powyżej, pełnił „Kurier Wileński”. Sytuacja ulega zmianie wraz z nowym rokiem. 30 grudnia 1927 roku władze Krajowego Stronnictwa Ludowego złożyły wniosek o wydawanie własnego pisma $^{33}$, a już pierwszego stycznia 1928 roku ukazał się pierwszy numer nowego polskiego czasopisma na ziemiach północno-wschodnich „Wioska”. W podtytule pisma znajdujemy informację, że było ono organem Krajowego Stronnictwa Ludowego Ziem Litewsko-Białoruskich „Zjednoczenie”. Redakcja nowego politycznego tygodnika, bo w takiej formule według założeń jego twórców miało być wydawane pismo ${ }^{34}$, mieściła się w lokalu stronnictwa przy ul. Mostowej 9/3. Pismo jako redaktor odpowiedzialny podpisywał Białorusin Michał Szukiewicz związany wcześniej między innymi z redakcją „Kuriera Wileńskiego”, gdzie pełnił funkcję redaktora odpowiedzialnego. Jednakże z meldunków sytuacyjnych wynika, że faktycznym redaktorem pisma był wspomniany Węckowicz ${ }^{35}$. Wydawcą pisma, które tłoczono w będącej własnością sprzyjającego stronnictwu Ludwika Chomińskiego drukarni „PAX”, był przewodniczący stronnictwa Raczkiewicz.

Należy zauważyć, że pomimo licznych prac tak z zakresu historii ruchu ludowego i prasy polskiej pismo to nie było dotychczas omawiane. Jedyne wzmianki o jego działalności znajdujemy u wspomnianego Traczuka, który klasyfikuje je jako „antyhromadowskie” pismo białoruskie wydawane w języku polskim, na co wpływ miała prawdopodobnie osoba redaktora odpowiedzialnego ${ }^{36}$. W świetle odnalezionych przeze mnie materiałów archiwalnych klasyfikacja ta nie może zostać utrzymana. Właściwsze wydaje się określenie „Wioski” jako prorządowego pisma wyborczego o propagandowym charakterze. Wskazuje również na to niewygórowana cena „Wioski” wynosząca jedynie 10 groszy. Dla porównania tyle samo kosztowały w tym czasie pojedyncze egzemplarze największych wileńskich pism codziennych „Dziennika Wileńskiego” i „Słowa”, jedynie cena „Kuriera Wileńskiego" wynosiła 20 groszy. Pismo kierowane było głównie do polskiej ludności wiejskiej na ziemiach północno-wschodnich II Rzeczpospolitej. Funkcję orga-

33 LCVA, F 51-7-698, k. 1v.

34 Pomimo iż w stopce redakcyjnej nie wskazywano na periodyczność pisma, w odniesieniu do ceny miesięcznej prenumeraty wynoszącej 40 groszy można przypuszczać, że w założeniu swych twórców Wioska miała być tygodnikiem.

35 LCVA, F 51-7-698, k. 1v; LCVA, F 15-2-379, k. 124.

36 J. Traczuk, op. cit., s. 323-324. 
nu prasowego KSL „Zjednoczenie” dla ludności białoruskiej pełnił bowiem wspomniany powyżej „Białoruski Dzień” Umiastowskiego. Nie podjęto natomiast próby pozyskania dla własnych celów prasy litewskiej, kierując do miejscowej ludności pojedyncze ulotki wyborcze, w których przedstawiano program i cele partii ${ }^{37}$.

Również analiza treści wyraźnie wskazuje na charakter pisma. W jedynie dwóch numerach pisma - drugi, a zarazem ostatni został wydany 10 stycznia 1928 roku - przeważają przedwyborcze artykuły propagandowe. W numerze pierwszym i drugim artykuły wstępne omawiały program polityczny stronnictwa. W pozostałych podejmowano problem relacji mieszkańców wsi z władzami administracyjnymi, szczególnie w zakresie korzystania z tzw. serwitutów ${ }^{38}$. Poza tym w obu numerach pojawiały się artykuły i polemiki charakterystyczne dla kampanii wyborczej, których ostrze skierowane było szczególnie przeciwko ogólnopolskim partiom ludowym ${ }^{39} \mathrm{i}$ białoruskiej Hromadzie ${ }^{40}$. Jedyną stałą w obydwu numerach rubryką nie mającą charakteru politycznego, były „Rady Gospodarskie”, zawierające porady rolnicze i hodowlane.

Zawieszenie pisma spotkało się z reakcją części sympatyków SKL „Zjednoczenie", którzy zażądali jego wznowienia lub zwrotu pobranych akonto prenumeraty pieniędzy. W związku z tym, władze stronnictwa rozważały możliwość jego reaktywacji, której jednak ostatecznie zaniechano. Fatalną sytuację pisma, pogłębiło ustąpienie Więckowicza po akcesie Krajowego Stronnictwa Ludowego „Zjednoczenie" do BBWR-u, ze sprawowanej funkcji redaktora pisma ${ }^{41}$. Wydarzenia te przesądziły o zakończeniu działalności wydawniczej „Wioski”.

\section{Wnioski}

Powstanie Krajowego Stronnictwa Ludowego Ziem Litewsko-Białoruskich „Zjednoczenie" należy traktować jako element prowadzonych w trakcie kampanii wyborczej przez BBWR działań zmierzających do osłabienia wyniku stronnictw opozycyjnych. W tych samych kategoriach należy oceniać powstanie organu prasowego stronnictwa „Wioska”, który miał pełnić w okresie kampanii wyborczej do Sejmu II kadencji funkcje propagandowe. Efemeryczne pismo KSL „Zjednocze-

\footnotetext{
${ }^{37}$ LCVA, F. 15-2-379, k. 10, 47, 140.

38 W., Nie musztrujcie wieśniaków, Wioska 1928, nr 1, s. 3-5; W., Drzewo na opat i na budulec dla wiosek, Wioska 1928, nr 2, s. 3-4.

${ }^{39}$ Nasza odpowiedź „Wyzwoleniu”, Wioska 1928, nr 1, s. 5-6; Na kiermaszu przedwyborczym, Wioska 1928, nr 2, s. 6-7.

40 Bądźcie ostrożni, Wioska 1928, nr 2, s. 4-5.

${ }^{41}$ LCVA, F. 15-2-379, k. 52, 124.
} 
nie" podobnie jak wiele innych powoływanych w tym czasie pełniło często funkcję ulotki wyborczej, rozprowadzanej wśród miejscowej ludności.

Z perspektywy wyników wyborów do Sejmu II kadencji działania te przyniosły oczekiwane przez obóz rządowy efekty. Dotychczas najsilniejsze polskie stronnictwo polityczne na ziemiach wschodnich II Rzeczpospolitej, to jest PSL „Wyzwolenie", które w wyborach do Sejmu I kadencji (1922-1927) uzyskało na terenach województw nowogródzkiego i wileńskiego poparcie ponad 160 tysięcy wyborców i wprowadziło z nich do Sejmu łącznie 10 posłów, w wyborach z roku 1928 uzyskało odpowiednio około 50 tysięcy głosów w wyniku czego mandat poselski do Sejmu uzyskała dotychczasowa senator klubu pochodząca z Wilna Aleksandra Karnicka ${ }^{42}$. Z pewnością wpływ na tak słaby rezultat partii ludowych w województwie wileńskim i nowogródzkim miały działania administracyjne, między innymi unieważnienie przez Okręgową Komisję Wyborczą w Wilnie lokalnej listy SCh na tydzień przed wyborami ${ }^{43}$.

Jednakże należy zauważyć, że pomimo podkreślanej przez cytowanego już A. Notkowskiego skali zaangażowania finansowego obozu rządowego w akcję wyborczą działania te nie pozwoliły na osiągnięcie zakładanych w perspektywie kadencji celów politycznych, na co wpływ miały tak działania opozycji oraz fakt, że wybory do Sejmu II kadencji w części okręgów w województwach wschodnich zostały unieważnione przez Sąd Najwyższy. Stąd też nie jest możliwe określenie faktycznego poparcia jakie otrzymały poszczególne partie polityczne na ziemiach północno-wschodnich II Rzeczpospolitej, a tym samym skali oddziaływania KSL „Zjednoczenie”. Szczególnie, że w konsekwencji wyroków Sądu Najwyższego swe mandaty utracili między innymi posłowie BBWR wybrani w okręgu wyborczym nr 64, między innymi prowadzący akcję wyborczą bloku względem opozycyjnych stronnictw ludowych, a także jeden z założycieli Krajowego Stronnictwa Ludowego Ziem Litewsko-Białoruskich „Zjednoczenie” Mieczysław Raczkiewicz ${ }^{44}$.

${ }^{42}$ T. i W. Pileccy, Sejm i Senat 1928-1933. Podręcznik dla wyborców, zawierajacy wyniki wyborów w powiatach, okręgach, województwach, podobizny postów sejmowych i senatorów, statystyki oraz mapy pogladowe, Poznań 1928, s. 337-350, 450; eidem, Sejm i Senat 1922-1927. Podręcznik dla wyborców, zawierający wyniki wyborów w powiatach, okręgach, województwach, podobizny senatorów i postów sejmowych oraz mapy poglądowe, Poznań 1923, s. 124-130.

${ }^{43}$ LCVA, F 15-2-379, k. 159.

44 Unieważnienie wyborów (B.B. Traci 9 mandatów), Kurier Warszawski, 15.04.1930, s. 5; Unieważnienie wyborów w okręgach święciańskim i kowelskim, Kurier Wileński, 15.04.1930, s. 1. 